\title{
An Overview and Informal Key of the Ferns of Florida ${ }^{1}$
}

\section{Douglas Scofield, Ginger Allen, and Martin Main² \\ Introduction}

According to fossil records, ferns and fern-like plants appeared on Earth 408 million to 438 million years ago and are among the oldest living plants on Earth. As might be expected, these ancient plants possess primitive traits. For example, ferns produce spores instead of seeds. Although spores are analogous to seeds in their reproductive role, they lack several characteristics of seeds, such as a seed coat. Also, a fern's life cycle includes distinct immature and mature stages that occur as separate plants (Figure 1).

This differs from more modern vascular plants in which immature and mature stages occur in the same plant. The ferns immature stage is called a prothallus. The prothallus possesses both male and female sex organs that make self-fertilization possible and initiates the development of the mature fern. As the fern grows from the underside of the prothallus, it unrolls in a characteristic growth form referred to as a fiddlehead, eventually reaches the mature stage, and produces spores to continue the life cycle.

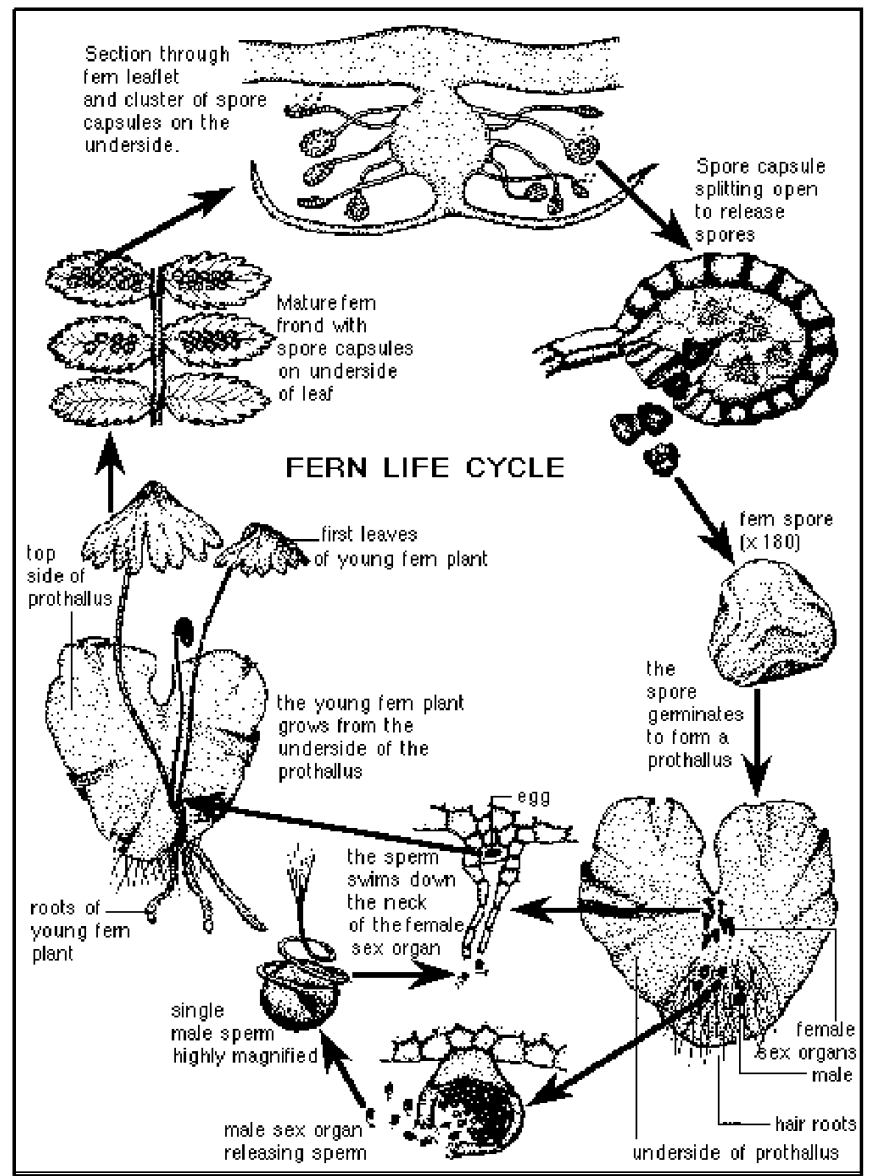

Figure 1. Fern Life Cycle Reproduced. Used with permission, (C) Murray Fagg

1. This document is Circular 1471, one of a series of the Wildlife Ecology and Conservation Department, Florida Cooperative Extension Service, Institute of Food and Agricultural Sciences, University of Florida. Published: May 2005. Please visit the EDIS Web site at http://edis.ifas.ufl.edu.

2. Douglas G. Scofield, post-doctoral associate, Department of Biology, Indiana University, Bloomington, IN; Ginger M. Allen, senior wildlife biological scientist, and Martin B Main, associate professor and extension wildlife specialist, University of Florida/IFAS, Southwest Florida Research and Education Center, Immokalee, FL.

The Institute of Food and Agricultural Sciences (IFAS) is an Equal Opportunity Institution authorized to provide research, educational information and other services only to individuals and institutions that function with non-discrimination with respect to race, creed, color, religion, age, disability, sex, sexual orientation, marital status, national origin, political opinions or affiliations. U.S. Department of Agriculture, Cooperative Extension Service, University of Florida, IFAS, Florida A. \& M. University Cooperative Extension Program, and Boards of County Commissioners Cooperating. Larry Arrington, Dean 


\section{Fern Growth Forms}

Learning to identify ferns requires knowing a few terms used to describe the mature plant. The frond is a fern leaf attached to the main axis of growth; the point of attachment may be below or above ground (Figure 2).

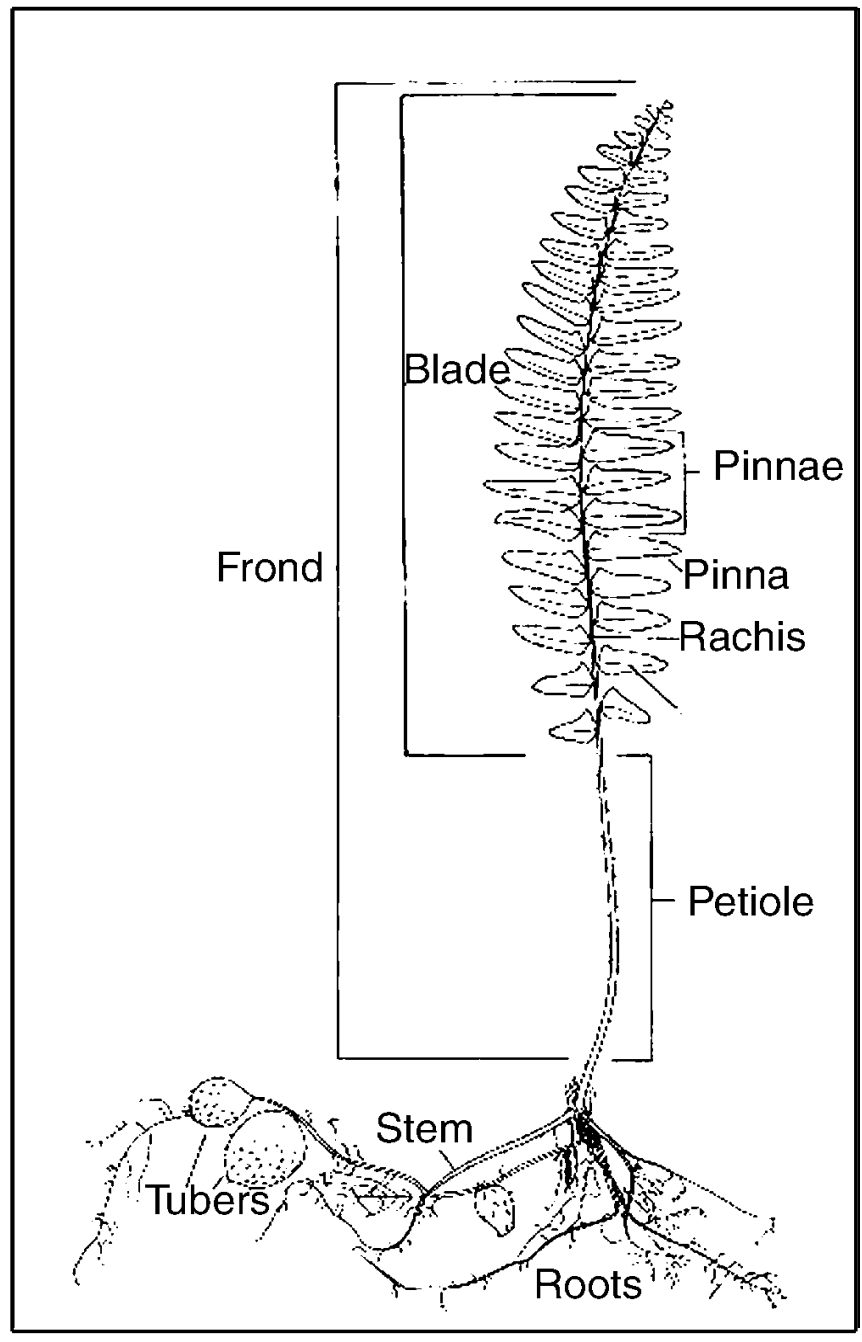

Figure 2. Fern Leaf and Root Structures. Reproduced with permission from IFAS publication SS-AGR-22

The frond includes the stem, which is known as the petiole, and the blade, which is the leafy portion of the frond. The blade form and shape varies depending on the species. The rachis is the extension of the petiole into the blade. The blade may be undivided (simple) or divided multiple times. Pinnate blades are divided into distinct leaflets called pinnae (singular: pinna). Pinnae are attached to the rachis by a small stem and have their own characteristics. For example, some species possess pinnatifid pinnae (Figure 3).

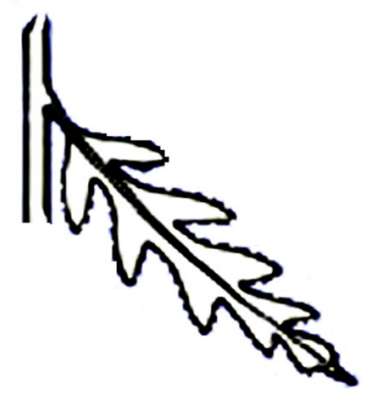

Figure 3. Pinnatifid leaf. Credits: By Ginger Allen

Terms are combined to describe fern growth forms. For example, a pinnate-pinnatifid fern has pinnae that are pinnate, attached to the rachis as in Figure 2, but each pinna is itself pinnatifid (see Figure 3 and Figure 4).

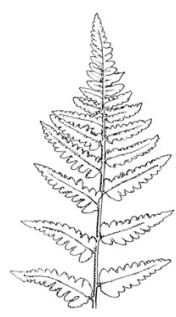

Figure 4. Pinnate-pinnatifid leaf blade. Credits: By Ginger Allen

Additional leaf divisions are shown in Figure 5 and Figure 6.

If pinnae are themselves subdivided, the divisions are called pinnules. Palmate blades have pinnae that are directly attached to the end of the petiole and extend outward from the center of the frond, extending like fingers from a person's palm. (Figure 7).

\section{Reproductive Structures and Fertile and Sterile Leaves}

Underneath a fern blade, you may find small spore casings containing many individual spores. The spore casings are referred to as sporangia, and clusters of sporangia are referred to as sori (Figure 8).

Sori typically form distinct patterns that are helpful for identifying different species. Sori may be 


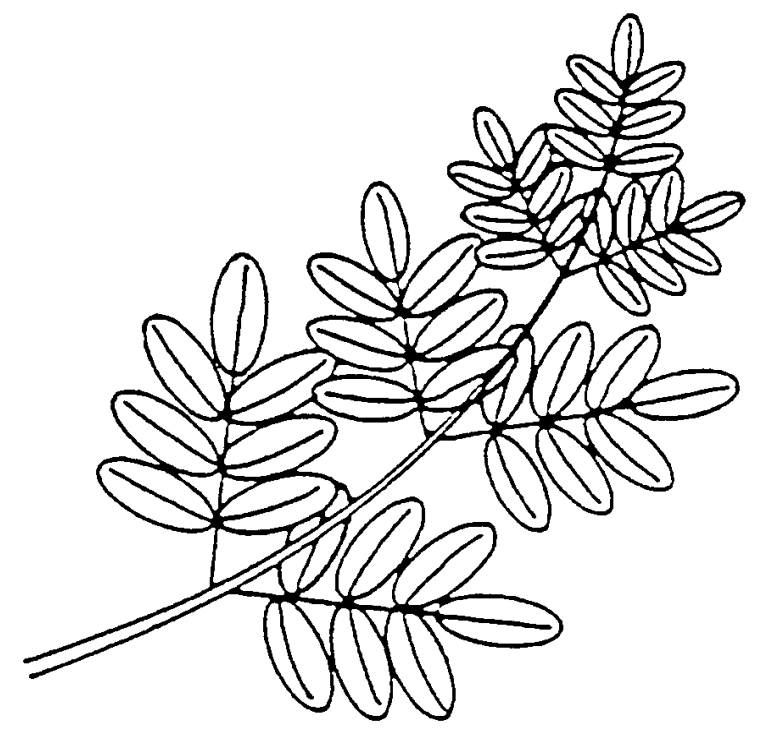

Figure 5. Bipinnate leaf blade. Credits: Reproduced with permission from the UF/IFAS Botany Handbook for Florida

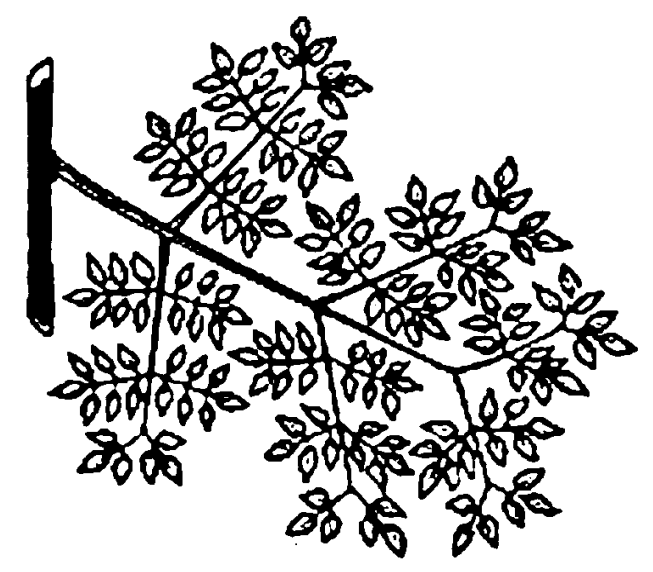

Figure 6. Tripinnate leaf blade. Credits: Reproduced with permission from the UF/IFAS Botany Handbook for Florida

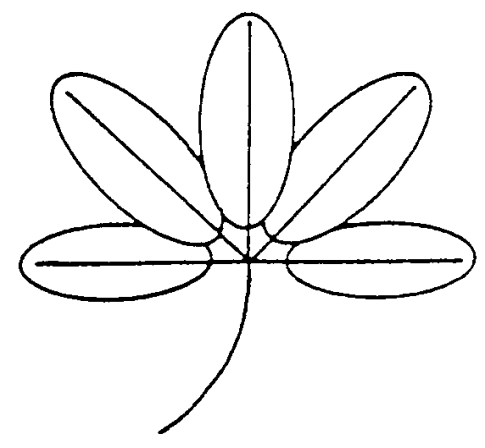

Figure 7. Palmate leaf blade. Credits: Reproduced with permission from the UF/IFAS Botany Handbook for Florida

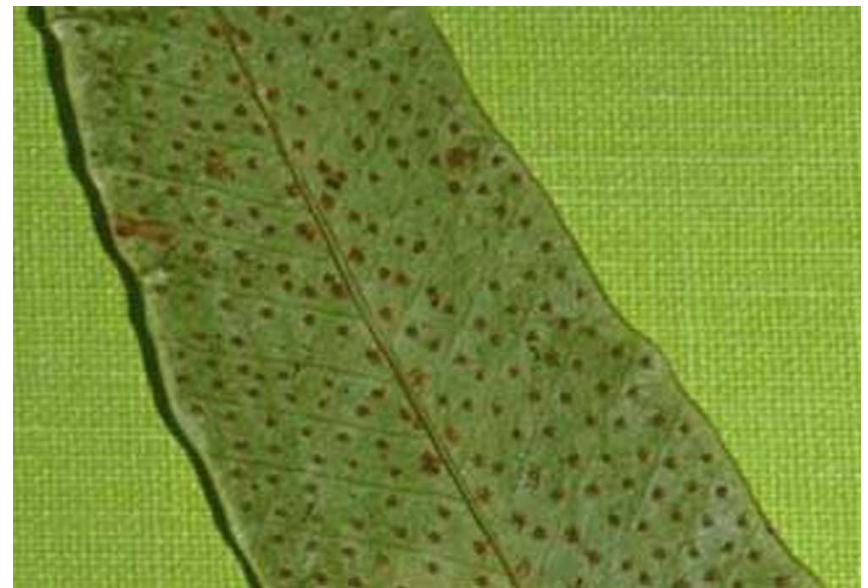

Figure 8. Sori on the underside of a Long Strap Fern (Campyloneurum phyllitidis) blade. Credits: By Doug Scofield

shaped like circular dots as in Figure 8, or be in short or long linear lines. Sori may follow the margins, midveins, or venation patterns of the pinnae or pinnules. Sometimes, sporangia completely cover the undersides of the pinnae, as in the Giant Leather Fern (Acrostichum danaeifolium), and individual sori cannot be seen.

Not every frond is fertile, or produces spores. Sterile fronds never produce spores. In some species with dimorphic fronds such as the Netted Chain Fern (Woodwardia areolata), fertile and sterile fronds have different shapes.

If you take a piece of mature fertile frond and place it face up inside a book overnight, the next day you may see that the spores have been released as a fine colored powder. The spore powder can be black, brown, red, yellow, or even green. Each of these spores is capable of growing into an adult fern and producing spores.

\section{Florida Ferns}

Florida's temperate to subtropical climate and abundant moisture create excellent growing conditions for ferns. Tropical storms and winds have transported fern spores to Florida from Caribbean islands and resulted in a high diversity of species. Consequently, Florida has more species of ferns than any state except Hawaii. There are an estimated 123 native fern and fern-like species, and at least 21 exotic and hybrid (crossbreeding of two species) species of ferns found in Florida. 
Florida's plant life was studied extensively by botanists beginning in the early 1800s. When the rich diversity of Florida's ferns became known in the early 1900 s, a large cut-foliage industry began. In 2002, there were 224 producers of leatherleaf ferns and other cut greens in Florida, with sales totaling $\$ 86.3$ million, making it one of the nation's leaders in this industry.

Conversion of natural areas to agriculture and urban land uses has resulted in the decline of natural areas and of several species of ferns. Florida has 43 species of ferns listed as endangered, seven as threatened, and three as commercially exploited. In particular, tropical species that occur only in moisture-rich, limestone habitats have suffered from land use changes. Conservation efforts to protect Florida's ferns include educational programs designed to prevent illegal collecting and programs that promote the protection of critical habitat.

\section{Simplified Key to Some Common, Unique, and Exotic Florida Ferns}

\section{1)Floating Plants}

a)Fronds round, fingertip-sized, bent in the middle; tiny hairs apparent upon close examination of the upperside; form loose mats: Water Spangles, Salvinia minima.

b)Fronds irregularly branched, like flattened juniper twig: Mosquito Fern, Azolla caroliniana.

\section{2)Simple Undivided Blades or Slender Branched Sticks}

a)Terrestrial or epiphytic; plant branched green sticks, to 6" or more; often in clumps: Whisk Fern, Psilotum nudum (Plate 1).

b)Mostly terrestrial, in moist soil; plant one or two rounded to elliptical fronds to 3" long; may have a separate spore stalk longer than the frond: Adders-Tongue Ferns, Ophioglossum spp.

c)Epiphytic; fronds slender, 1/2" wide or less, hanging like bunches of spinach linguine: Shoestring Fern, Vittaria lineata.
d)Epiphytic, often on fallen trunks; fronds much wider than 1/2", strap-shaped, arching; underside of blade with many round sori (Figure 7); common: Strap Fern, Campyloneurum phyllitidis.

\section{3)Palmately Divided Blades (Handlike)}

a)Fronds 1" to 2" long; forms thick climbing mats: Climbing Ferns, Lygodium spp., Invasive Exotic.

b)Fronds 4" to 12" long; epiphytic on Cabbage Palm (Sabal palmetto) trunks; frequently poached; rare: Hand Fern, Ophioglossum palmata (Plate 2).

\section{4)Pinnatifid Blades, or Mostly So}

a)Terrestrial plant of hammocks with dimorphic fronds; sterile fronds light green.

i)Lower pinnae of sterile fronds shallowly lobed; fertile fronds shorter, appearing "beaded"; found in northern Florida: Sensitive Fern, Onoclea sensibilis.

ii)Fertile fronds similar in height and shape to sterile fronds but with much more narrow "skinny" pinnae: Netted Chain Fern, Woodwardia areolata.

b)Terrestrial plant of hammocks; shiny dark green fronds, about as long as wide; pinnae curved; rare: Broad Halberd Fern, Tectaria heracleifolia (Plate 3).

c)Usually epiphytic; fronds 10" or longer; rhizome thickly covered with golden hairs and finger-thick; often found on tree trunks or cabbage palms; common: Cabbage Palm Fern, Phlebodium aureum (Plate 4).

d)Epiphytic; fronds 6" or smaller; in clumps on tree branches; fronds curl up and dry out during periods of low moisture, then uncurl and turn green with rain; common: Resurrection Fern, Polypodium polypodioides.

\section{5)Pinnate Blades}

a)Large terrestrial plants, up to 3 ' or more in length and $1.5^{\prime}$ or more wide; wide pinnae, 1 " or more. 
i)Plants in moist/fresh water area with smooth pinnae; over 30 pairs of pinnae, closely crowded on rachis: Giant Leather Fern, Acrostichum danaeifolium (Plate 5).

ii)Plants in brackish water or near coasts with smooth pinnae; fewer than 20 pairs of pinnae, spread along rachis: Coastal Leather Fern, Acrostichum aureum.

iii)Plants of hammocks; several pairs of coarse pinnae; blade pinnatifid at the tip: Incised Halberd Fern, Tectaria incisa, Invasive Exotic.

b)Plants usually terrestrial, fronds relatively narrow, 4x or more longer than wide, "Boston Ferns."

i)Fronds usually $2^{\prime}$ or longer; pinnae more than four times longer than wide, found in swamps and wet hammocks: Giant Sword Fern, Nephrolepis biserrata (Plate 6).

ii)Fronds taper towards tip and base; bases of pinnae overlap; each pinna divided by its midrib into two clear unequal portions; hairlike scales on rachis; round tubers often found on roots: Tuberous Sword Fern, Nephrolepis cordifolia, Invasive Exotic.

iii)Pinnae not overlapping; midrib divides pinna into two roughly equal portions; tips narrow and curving: Wild Boston Fern, Nephrolepis exaltata.

c)Fronds narrow; pinnae each typically 1 to 4 longer than wide, and often with shallowly toothed edges; sori linear, short, angled along the veins; rachis may be black to green.

i)Terrestrial; blackish petiole and rachis; pinnae taper at the ends and lobed at the base, crowded along the rachis; common: Ebony Spleenwort, Asplenium platyneuron.

ii)As (i) above but epiphytic with green petiole and rachis, and fewer pairs of pinnae spaced along the rachis; uncommon: Eared Spleenwort, Asplenium auritum.

iii)Pinnae squarish: several other species of Spleenwort Ferns, Asplenium spp.
d)Frond light to medium green; edges of pinnae finely toothed, obvious to the touch; Sori linear, long, located along both sides of the pinnae midribs; petiole and rachis green; common: Swamp Fern, Blechnum serrulatum (Plate 7).

e)Frond dark green; Sori located along the margins of the pinnae; terminal pinna at end of rachis longer than nearly all other pinnae: Chinese Brake Fern, Pteris vittata, Exotic.

\section{6)Pinnate-Pinnatifid Blades}

a)Fertile and sterile fronds dimorphic; fronds held upright, to 36 " tall or a little more; sterile fronds somewhat shiny, with the underside of each pinna having a small tuft of golden rusty hairs at the base; fertile-frond pinnae smaller than sterile-frond pinnae, covered with cinnamon-colored sporangia; species common in moist areas: Cinnamon Fern, Osmunda cinnamomea.

b)Sori linear, arranged in chain-like rows along both sides of the midribs of pinnae and the midveins of pinnules: Virginia Chain Fern, Woodwardia virginica (Plate 8 ).

c)Sori linear, angled; pinnae edges irregular or shallowly toothed: several species of Spleenwort Ferns, Asplenium spp. Asplenium abscissum is illustrated on Plate 9.

d)Sori round, on underside of frond.

i)Frond upperside smooth with no or only a few hairs.

(1)Upperside of blade typically shiny and without hairs; pinnae 5 to 10 longer than wide; pinnules appearing broad, with separations between pinnules usually extending no more than about half-way to midrib of pinna; sori in winding row along edge of pinnules: Hottentot Fern, Thelypteris interrupta.

(2)Upperside of blade lacking hairs or with only a few; pinnules appearing narrow, with separations between pinnules extending to $3 / 4$ of the way to midrib of pinna: Ovate Maiden Fern, Thelypteris ovata. 
(3)Pinnae mostly alternate, 1-4" long, 1" wide, lateral veins forked near tip: Marsh Fern, Thelypteris palustris.

(4)Pinnae alternate along rachis; edges of pinnae shallowly lobed; fertile pinnae restricted to upper portion of blade: Southern Wood Fern, Dryopteris ludoviciana (Plate10).

ii)Frond upperside somewhat to definitely hairy.

(1)Fronds terrestrial; stems and underside hairy, upperside somewhat hairy; pinnae lobes separated; common: Widespread Maiden (Shield) Fern, Thelypteris kunthii (Plate 11). Also may be one of several other species in the genus Thelypteris, which are common throughout the state.

(2)Lower stems of fronds not covered with short golden hairs; pinnae lobes closely spaced; uncommon: Downy Maiden Fern, Thelypteris dentata.

(3)Lower stems of fronds covered with short golden hairs; uncommon: Brown-hair Comb Fern, Ctenitis submarginalis.

(4)Fronds small, colonies of single fronds, on vertical limestone faces, hairs on fronds in star-shaped clumps: Creeping Star-hair Fern, Thelypteris reptans.

7)Bipinnate Blades - Only one species in Florida. Found in moist areas; large fronds 2' to 5' long, pinnules have finely serrated edges; dimorphic but fertile fronds not always apparent, when present coated with brown sporangia: Royal Fern, Osmunda regalis var. spectabilis (Plate 12).

\section{8)Bipinnate-Pinnatifid, Bipinnate-Bipinnatifid to Tripinnate Blades}

a)Small, short terrestrial plants with dimorphic fronds. One sterile frond, small and more or less triangular; one fertile frond, taller than the sterile frond and topped with bead-like sporangia: Grapeferns, Botrychium spp.(Plate 13).

b)Terrestrial plants, common in pinelands; pinnules small, trapezoidal; frond is sterile except for lowermost pair of pinnae which are held vertically and covered with sporangia: Pine Fern, Anemia adiantifolia (Plate 14).
c)Large, broadly triangular fronds, appearing delicate or 'lacy," 2' to 3' in length or more; pinnules with dissected edges.

i)Bases of petioles covered with rusty hairs; petiole and rachis rusty to brownish; southern Florida: Florida Tree Fern, Ctenitis sloanei.

ii)Bases of stems green; petiole and rachis green to yellowish; blade may appear "stepped," with pinnae slightly twisted on the rachis: Mariana Maiden Fern, Macrothelypteris torresiana, Exotic.

d)Fronds large but not appearing lacy; fronds stiff, shiny; pinnae evenly rounded, smooth-edged; sori linear, along margins of pinnules; width of pinnae lobes approximately 0.5 "; common in dry areas with frequent fires: Bracken Fern, Pteridium aquilinum. The Giant Brake Fern, Pteris tripartita, Exotic, is similar but occurs in moist soils and has softer fronds.

\section{Plates}

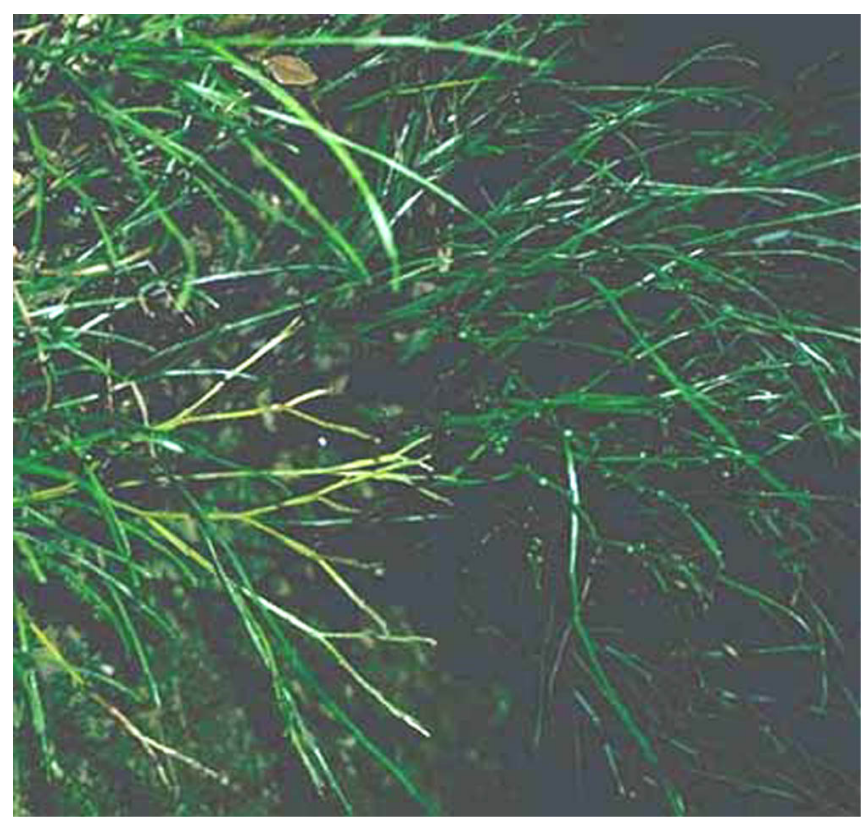

Plate 1. Whisk Fern. Not a true fern. Green, simple, paired, stick-like branches. Tiny scales along the branches replace leaves. Sporangia are yellow lobes along branches. Forms large clumps in crooks of trees or occasionally terrestrial in hammocks and gardens. 


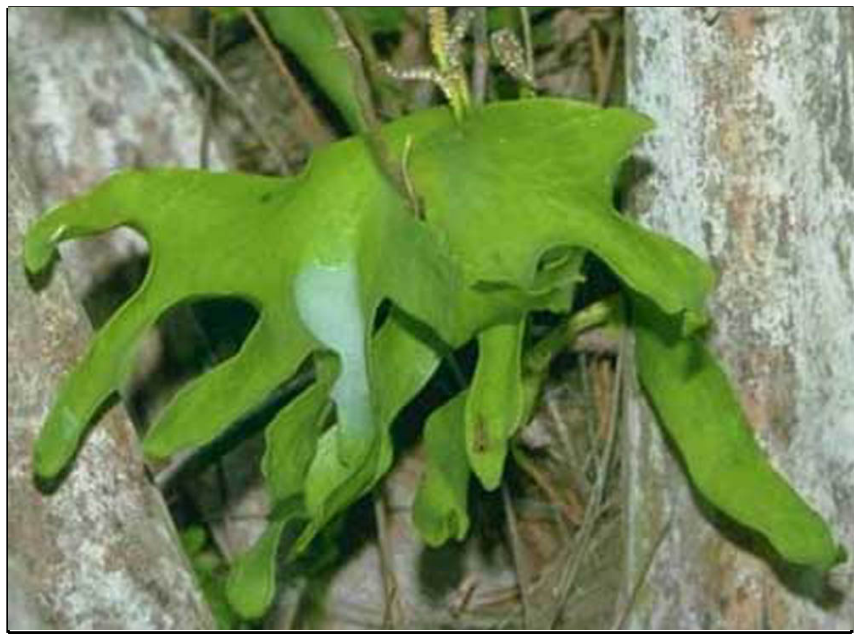

Plate 2. Hand Fern. Formerly widespread throughout the southern half of the state, now very rare due to poaching. Found only in the debris collected in old palm frond boots.

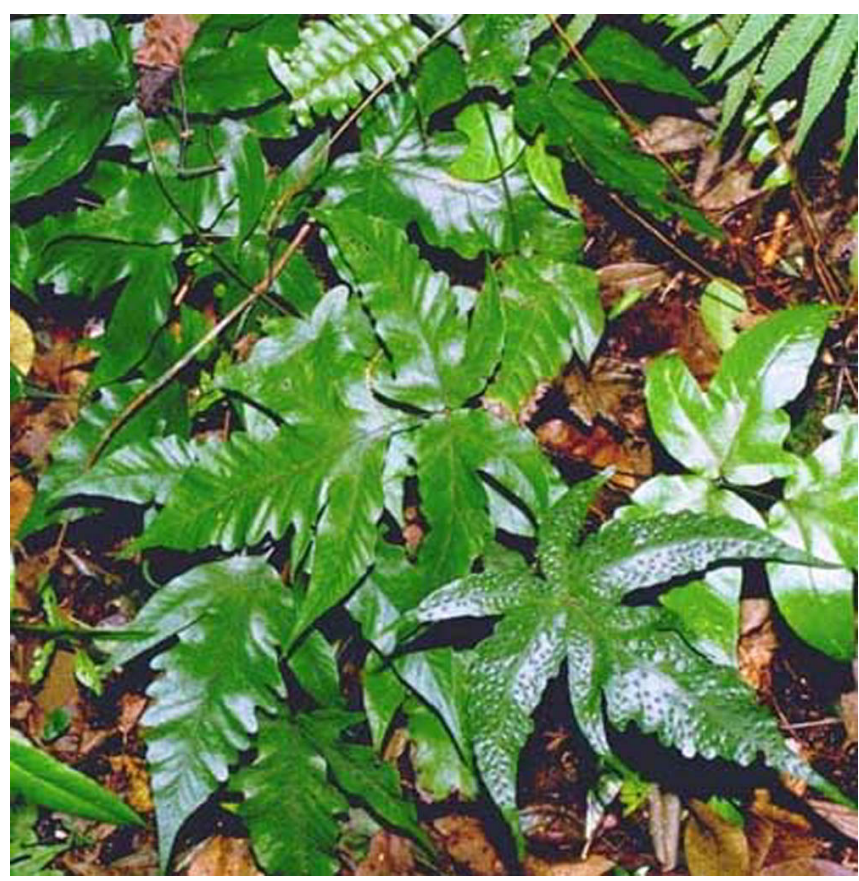

Plate 3. Bald Halberd, State Endangered. Named after a medieval spearhead. Found in colonies on limestone outcrops, near sinkholes, and in rocky hammocks.

Australian National Herbarium, The Fern Pages, available online at:

http://www.anbg.gov.au/projects/fern/

Florida Department of Agriculture and Consumer Services, History of the Fern Industry in Florida, available online at: www.florida-agriculture.com/consumers/ fern_history.htm

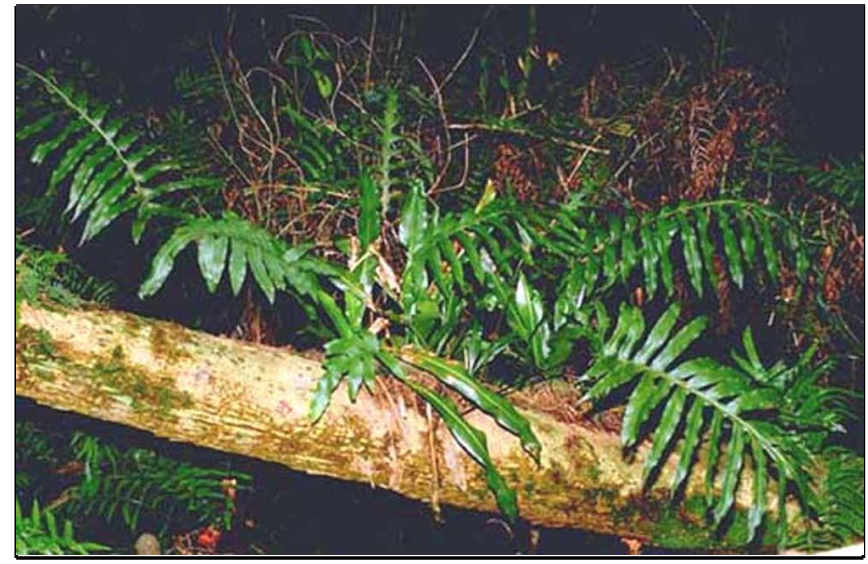

Plate 4. Cabbage Palm Fern. This is the most visible fern species in southern and central Florida. It grows in Cabbage Palm (Sabal palmetto) boots, the bark of Live Oaks (Quercus virginiana), or other nutrient-rich nooks. Mostly epiphytic, but sometimes terrestrial in rich, well-drained soils. The wavy, parchment-like, incompletely divided, widely lobed fronds and thick hairy rhizomes are unique.

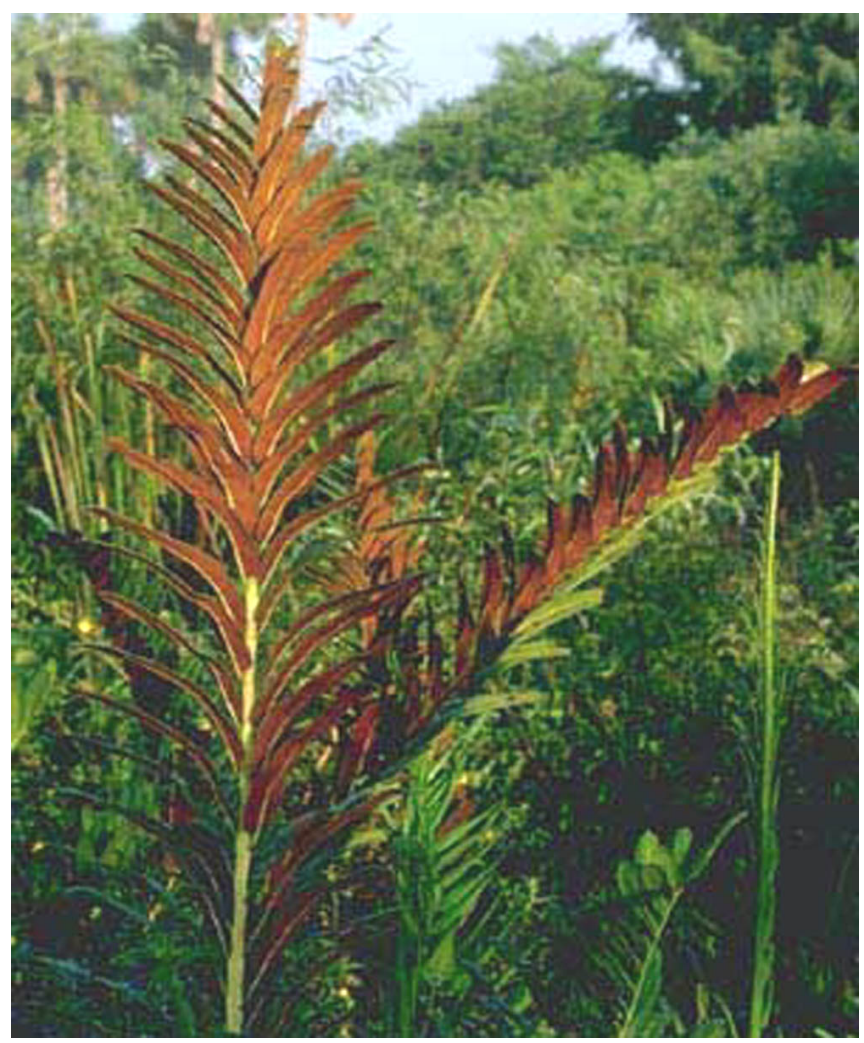

Plate 5. Giant Leather Fern. This fern prefers to grow in wetland areas. The fronds grow over 6 ' in length, and the leaves are thick. Brown sori cover undersides of fertile fronds.

Florida Department of Agriculture and Consumer Services, Division of Plant Industry, Notes on Florida's Endangered and Threatened Plants, available online at: 


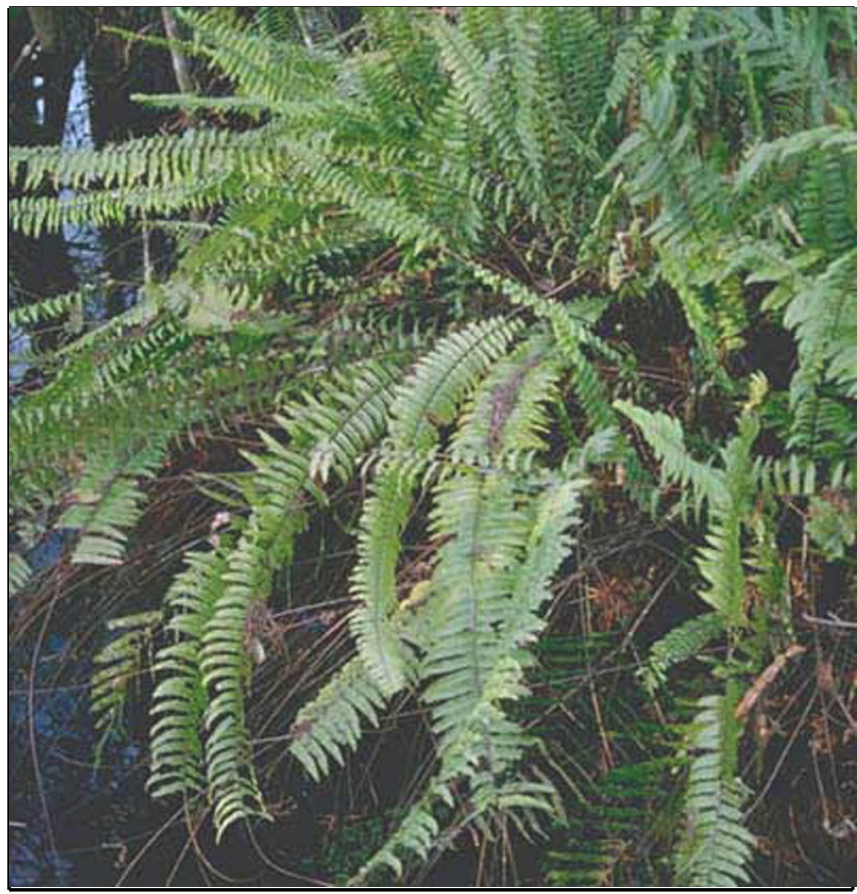

Plate 6. Giant Sword Fern. Fronds of this large species may extend several feet from moist to wet soil. The species name comes from tiny teeth that alternate with larger teeth along the edge of each lance-like pinna. Underneath each pinna, round sori occur evenly around the entire edge.

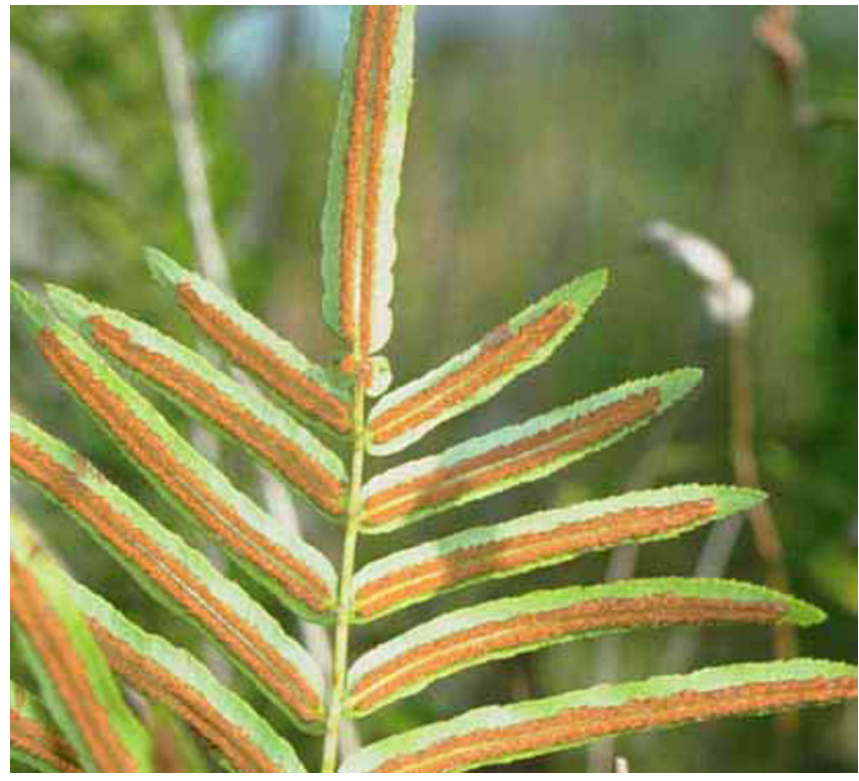

Plate 7. Swamp Fern. Found in the swamp but also in sandy upland hammocks. Pinnae edges are serrated.

http://www.doacs.state.fl.us/pi/enpp/botany/images/ Notes2003.pdf.

Lakela, O. and R. K. Long. 1976. Ferns of Florida. Banyan Books, Miami. 178 pp.

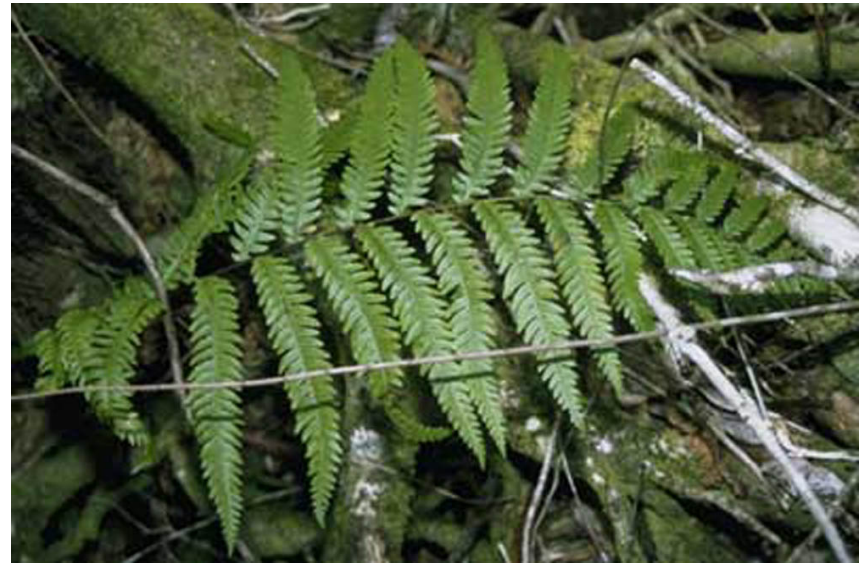

Plate 8. Virginia Chain Fern. Prefers acid soils, of Everglades tree islands, pinelands, marshes, and roadsides. Base of petiole and rachis dark brown.

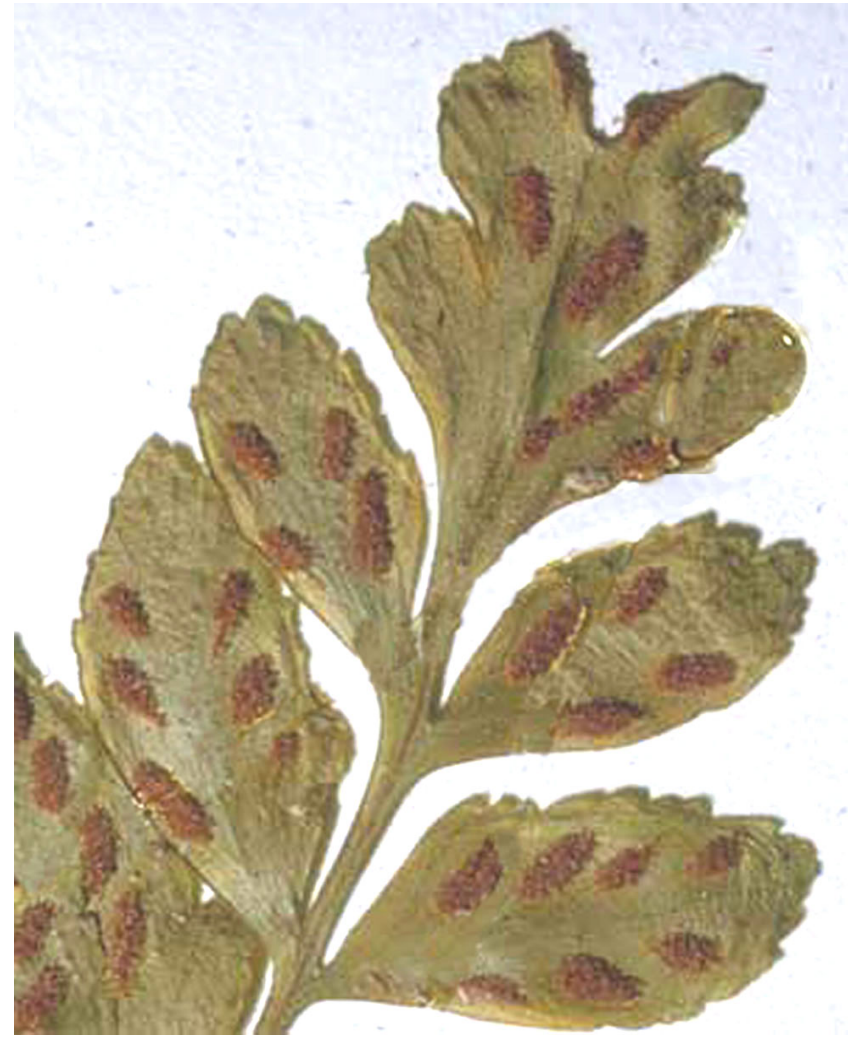

Plate 9. Cutleaf Spleenwort. Found on limestone outcrops and in hammocks. Small or absent lobes, petiole furrowed. Spleenworts were used by Greek gods to treat spleen disorders.

Langeland, K. A., 2001. Natural Area Weeds: Distinguishing Native and Non-Native "Boston Ferns" and "Sword Ferns" (Nephrolepis spp.) available online at: http://edis.ifas.ufl.edu/AG120

Lellinger, D. B. 1985. Ferns \& Fern-Allies of the United States and Canada. Smithsonian Institution Press, Washington, DC. 389 pp. 


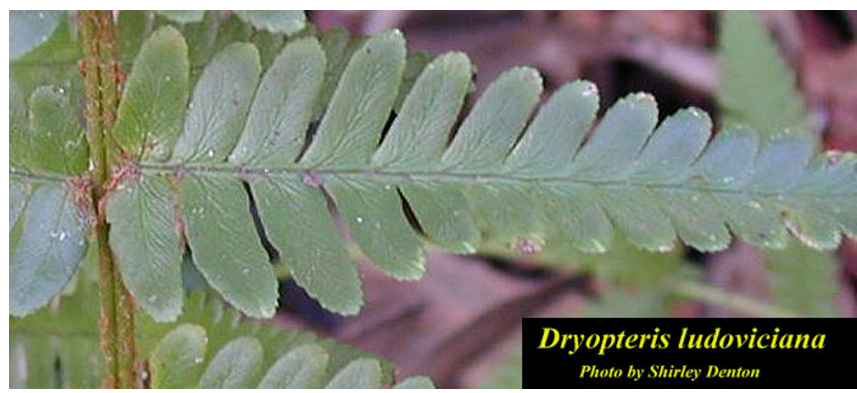

Plate 10. Southern Wood Fern. Only member of this genus (Dryopteris) found in Florida. Found in swamps, wet wood and hammocks, and limestone outcrops.

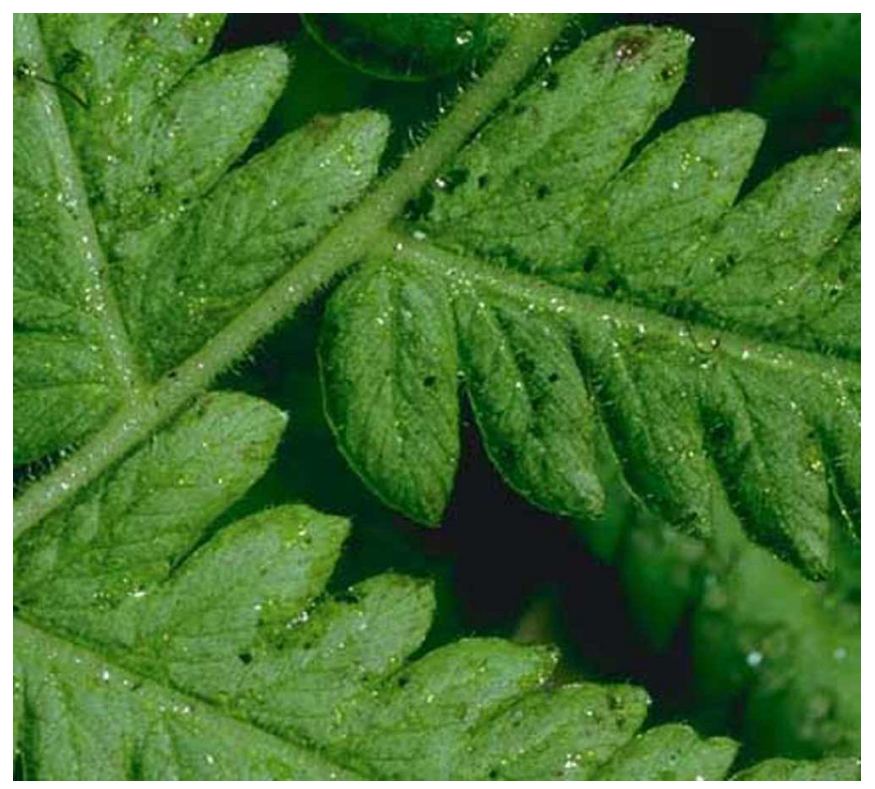

Plate 11. Widespread Maiden Fern. Found in wooded, limestone, and wetland areas. Stems creeping.

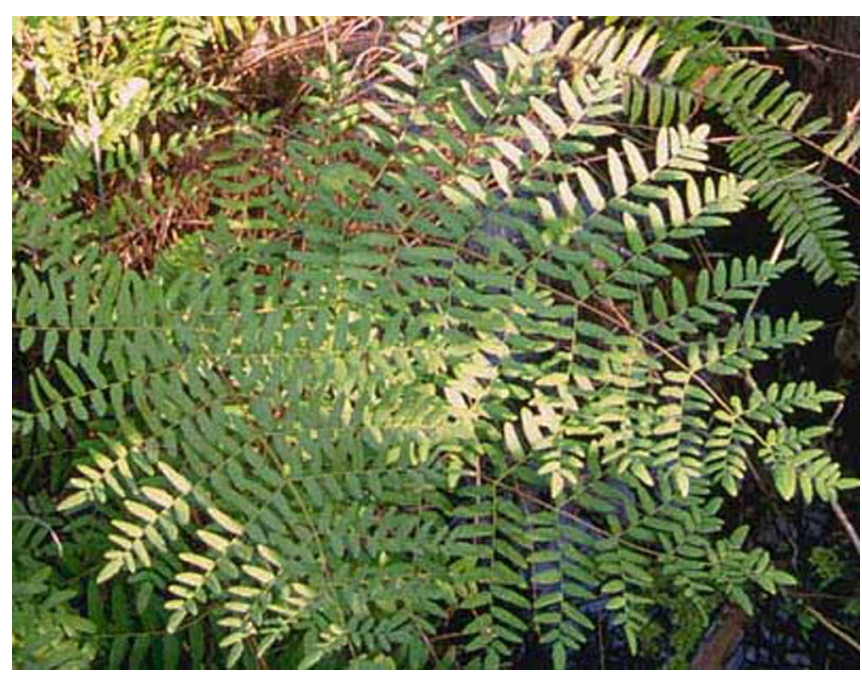

Plate 12. Called Royal Fern for its very large fronds, it grows in clumps. Stem fibers were used to make ropes and fishing nets. Leaves and other parts were used as early medical remedies for bone and muscle problems.

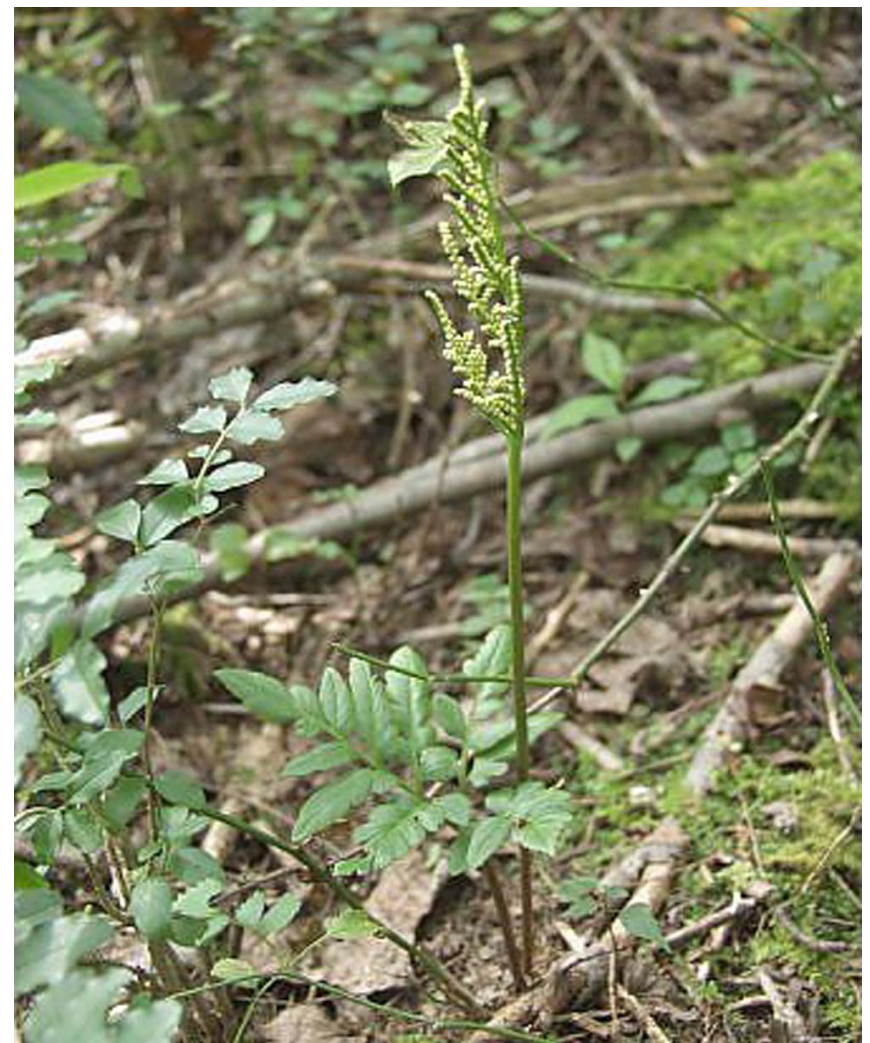

Plate 13. Southern Greapefern, Botrychium biternatum. Prefers moist woods but will grow in dry forests.

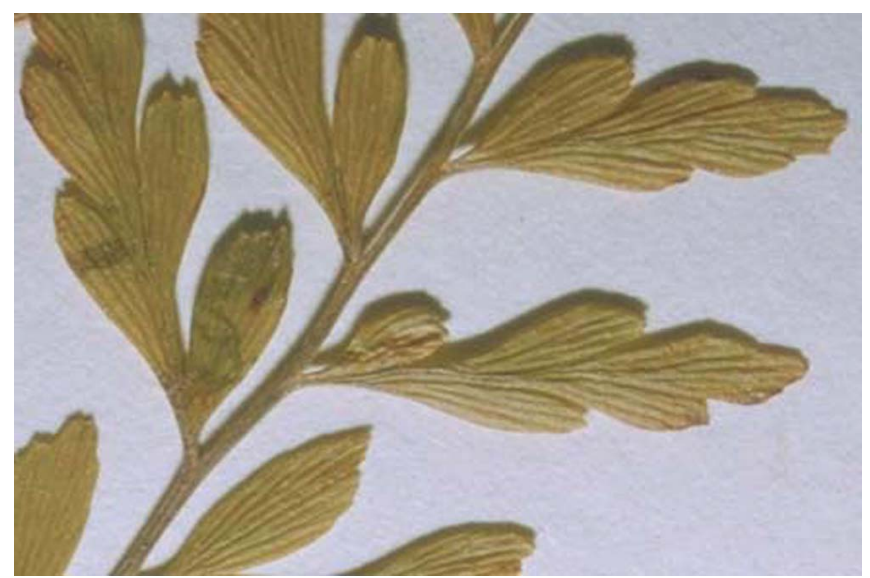

Plate 14. Pine Fern. Found in open pinelands, upland limestone hammocks, and near sinkholes. Plants smaller in dryer soils.

Nelson, G. 2000. The Ferns of Florida. Pineapple Press, Sarasota, Florida. 208 pp.

Osborne, L.C. Florida Fern Caterpillar, available online at:

http://www.mrec.ifas.ufl.edu/lso/entomol/ncstate/ cater9.htm

Scofield, D. G. Ferns of Fern Forest and South Florida, available online at: 
http://fig.cox.miami.edu/ scofield/sofl_plants/

fern_index.html

The American Fern Society, available online at: http://amerfernsoc.org/.

\section{Image Plate Credits}

Plates 1-9, 11, 12, and 14 by Douglas G.

Scofield, reproduced with permission.

Plates 10 and 13 by Shirley Denton, reproduced with permission. 